\title{
Oral submucous fibrosis: an update
}

This article was published in the following Dove Press journal:

Clinical, Cosmetic and Investigational Dermatology

13 April 2015

Number of times this article has been viewed

\author{
Uwe Wollina' \\ Shyam B Verma ${ }^{2}$ \\ Fareedi Mukram $\mathrm{Ali}^{3}$ \\ Kishor Patil ${ }^{4}$ \\ 'Department of Dermatology and \\ Allergology, Academic Teaching \\ Hospital Dresden-Friedrichstadt, \\ Dresden, Germany; ${ }^{2}$ Nirvana \\ Skin Clinic, Vadodara, Gujarat, \\ India; ${ }^{3}$ Departments of Oral and \\ Maxillofacial Surgery, SMBT Dental \\ College, Sangamner, Maharashtra, \\ India; ${ }^{4}$ Departments of Oral Pathology \\ and Microbiology, SMBT Dental \\ College, Sangamner, Maharashtra, \\ India
}

\begin{abstract}
Oral submucous fibrosis (OSF) is a premalignant condition caused by betel chewing. It is very common in Southeast Asia but has started to spread to Europe and North America. OSF can lead to squamous cell carcinoma, a risk that is further increased by concomitant tobacco consumption. OSF is a diagnosis based on clinical symptoms and confirmation by histopathology. Hypovascularity leading to blanching of the oral mucosa, staining of teeth and gingiva, and trismus are major symptoms. Major constituents of betel quid are arecoline from betel nuts and copper, which are responsible for fibroblast dysfunction and fibrosis. A variety of extracellular and intracellular signaling pathways might be involved. Treatment of OSF is difficult, as not many large, randomized controlled trials have been conducted. The principal actions of drug therapy include antifibrotic, anti-inflammatory, and antioxygen radical mechanisms. Potential new drugs are on the horizon. Surgery may be necessary in advanced cases of trismus. Prevention is most important, as no healing can be achieved with available treatments.
\end{abstract}

Keywords: betel nut, betel quid, oral disease, squamous cell carcinoma, tobacco, fibrosis

\section{Introduction}

Oral submucous fibrosis (OSF) is a premalignant disorder associated with the chewing of areca nut (betel nut). The habit is prevalent in South Asian populations but has been recognized nowadays also in Europe and North America. OSF causes significant morbidity. After transformation into squamous cell carcinoma (SCC), it is also responsible for mortality. The combination of areca nut and tobacco has led to a sharp increase in the frequency of OSF. ${ }^{1}$

Definition and clinical manifestations of the disease are summarized in Table 1. The initial presentation of OSF is inflammation. Inflammation is followed by hypovascularity and fibrosis visible as blanching of the oral mucosa with a marble-like appearance. Blanching may be localized, diffuse, or reticular. In some cases, small vesicles may develop that rupture and form erosions. ${ }^{1}$

In the later advanced stage of OSF, a fibrous band that restricts mouth opening (trismus) is characteristic. It causes further problems in oral hygiene, speech, mastication, and possibly swallowing. Development of fibrous bands in the lip leads to thickening and rubbery appearance. It becomes difficult to retract or evert the lips, which transform into an elliptical shape. A cross-sectional study in 325 patients in Karachi, Pakistan demonstrated a strong association among labial bands, bands in the fauces, and buccal bands. On the other hand, buccal bands had a weaker association to labial bands. ${ }^{2}$
Correspondence: Uwe Wollina Allergology, Academic Teaching Hospital Dresden-Friedrichstadt, Friedrichstrasse 4I, 01067 Dresden, Germany

Tel $+4935 \mid 480$ I 685

Fax +4935I 480 I219

Email wollina-uw@khdf.de 
Table I Histopathological classifications of oral submucous fibrosis

\begin{tabular}{|c|c|c|c|}
\hline Very early (stage I) & Early (stage II) & Moderately advanced (stage III) & Advanced (stage IV) \\
\hline $\begin{array}{l}\text { A finely fibrillar collagen, dispersed } \\
\text { with marked edema }\end{array}$ & $\begin{array}{l}\text { The juxta-epithelial area shows } \\
\text { early hyalinization }\end{array}$ & ized & $\begin{array}{l}\text { The collagen is } \\
\text { completely hyalinized }\end{array}$ \\
\hline The fibroblastic response is strong & $\begin{array}{l}\text { Plump young fibroblasts are present } \\
\text { in moderate numbers }\end{array}$ & $\begin{array}{l}\text { The fibroblastic response is less } \\
\text { marked, the cells present being } \\
\text { mostly adult fibrocytes }\end{array}$ & $\begin{array}{l}\text { The hyalinized areas are } \\
\text { devoid of fibroblasts }\end{array}$ \\
\hline $\begin{array}{l}\text { The blood vessels are sometimes } \\
\text { normal, but more often they are } \\
\text { dilated and congested }\end{array}$ & $\begin{array}{l}\text { The blood vessels are dilated } \\
\text { and congested }\end{array}$ & $\begin{array}{l}\text { Blood vessels are normal } \\
\text { or constricted }\end{array}$ & $\begin{array}{l}\text { Blood vessels are } \\
\text { completely obliterated } \\
\text { or narrowed }\end{array}$ \\
\hline $\begin{array}{l}\text { Inflammatory cells, mainly } \\
\text { polymorphonuclear leukocytes with } \\
\text { an occasional eosinophil, are present }\end{array}$ & $\begin{array}{l}\text { Inflammatory cells are mostly } \\
\text { mononuclear lymphocytes, eosinophils, } \\
\text { and an occasional plasma cell }\end{array}$ & $\begin{array}{l}\text { Inflammatory exudates consist of } \\
\text { lymphocytes and plasma cells, although } \\
\text { an occasional eosinophil is seen }\end{array}$ & $\begin{array}{l}\text { Inflammatory cells } \\
\text { are lymphocytes and } \\
\text { plasma cells }\end{array}$ \\
\hline
\end{tabular}

The severity of trismus can be graded by measuring the interincisor opening or mouth opening. The mouth opening is categorized into stage I $(>3 \mathrm{~cm})$, stage II $(2-3 \mathrm{~cm})$, and stage III $(<2 \mathrm{~cm}) \cdot{ }^{3-5}$ Fibrosis makes cheeks thick and rigid. The cheek flexibility may also be used to classify the severity of OSF. Three categories have been suggested: cheek flexibility $>30 \mathrm{~mm}, 20-30 \mathrm{~mm}$, and $<20 \mathrm{~mm}$. ${ }^{1}$

Clinical features of advanced OSF include the loss of puffed-out appearance of cheeks when a patient blows a whistle. Fibrosis of tongue and mouth impairs tongue movement and leads to depapillation and blanching of mucosa. ${ }^{1}$

Fibrosis may also affect the soft palate and uvula, whereas gingival involvement is relatively uncommon. Sometimes the blockage of Eustachian tubes impairs hearing, and esophageal fibrosis causes problems in swallowing. ${ }^{1}$

\section{Epidemiology}

Approximately 600 million persons are betel chewing, with a hot spot throughout the Western Pacific basin and South Asia. This makes betel the fourth most-consumed drug after nicotine, ethanol, and caffeine..$^{6,7}$

Betel is composed of the areca nut (Areca catechu), the fresh leaf of betel pepper (Piper betle), spices, and calcium hydroxide (lime) (Figure 1A and B). Pan or paan masala is a quid of piper betel leaf. ${ }^{8}$ Mawa is a mixture of tobacco, lime, and areca nut. Chewing tobacco or guthka became very popular, and betel chewers often also used guthka. However, guthka has recently been officially banned from the Indian market, ${ }^{9-11}$ but chewing tobacco-containing betel quid has become one of the most popular habits in South Asia. ${ }^{12}$ Since there is a lot in common between the various areca nut mixtures (pan, mawa) we will not differentiate between them. Betel is now widely available in the Western world as well. ${ }^{13}$
OSF subjects are younger and have shorter histories of chewing compared to chewers without OSF. OSF does not disappear after cessation of the habit but remains permanent. ${ }^{14}$

A study from Gujarat has shown that the prevalence of OSF is increasing - from $0.16 \%$ (1967) to $10.9 \%$ (1998). About $85 \%$ of patients were younger than 35 years. ${ }^{10}$ In 2005 , the OSF prevalence among visitors at a dental school in Manipal, India was estimated as $2 \%$, with a preference for
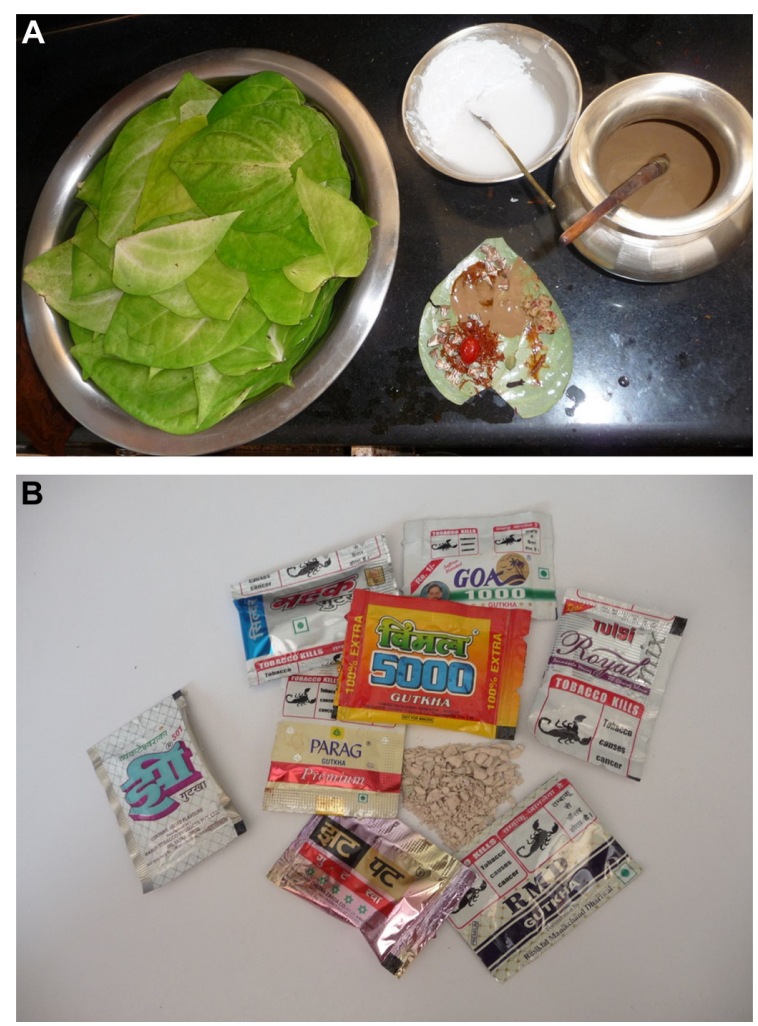

Figure I Handmade and commercial forms of betel.

Notes: (A) Typical ingredients of hand-made betel quid: green piper betel leaves (left), areca nut (lower right), slaked lime (upper left), and a mixture of spices (upper right). (B) Some commercial brands ready to use. 
male sex and an age range of 40-60 years. ${ }^{15}$ The prevalence of OSF in an aboriginal community of southern Taiwan was $17.6 \%$. Although the betel quid in Taiwan does not contain any tobacco, in contrast to India and Pakistan, a significant association with oral mucosal lesions was still identified. $^{16}$

In a study from Allahabad, India, 239 OSF patients were studied; $46 \%$ were in their 3 rd decade of life. The most common affected site was buccal mucosa $(20.8 \%)$, followed by palate $(17.7 \%)$. Trismus was observed in $37.2 \%$ of patients, $25.9 \%$ suffered from burning sensations, $22.5 \%$ reported excessive salivation, and $14.2 \%$ suffered from recurrent oral ulcerations. $^{3}$

Grading OSF in relation to addiction habits demonstrated a dependence from years of addiction and frequency of chewing betel and tobacco. Most patients with stage I OSF were addicted for at least 3-5 years, whereas the majority of patients with stage III OSF had consumed betel and tobacco products for 8-10 years or more with a frequency of 6-10 times per day. Trismus was seen more often in stage II and III OSF, but a clear correlation between the severity of trismus and OSF staging was missing. ${ }^{3}$

\section{Major constituents of areca nuts}

Areca nuts contain a great variety of substances. In the light of OSF, the most interesting compounds are those that are water or ethanol soluble. The alkaloid fraction contains arecoline, arecaidine, guvacine, guvacoline, arecolinidine, and others. The most predominant polyphenols are catechin, flavonoids, flavan-3:4-diols, leucocyanidins, hexahydroxyflavans, and tannin. Minor polyphenols include epicatechin, gallic acid, gallotannic acid, D-catechol, phiobatannin, and others. Furthermore, nitrosamines have been identified in areca nuts. Areca nuts also contain trace elements like copper, bromide, vanadium, manganese, chlorine, and calcium. ${ }^{17}$ Betel quid chewers are exposed to increased concentrations of potentially hazardous compounds such as arsenic, cadmium, copper, and lead. ${ }^{18}$

\section{Pathogenic factors in precancerous and cancerous lesions induced by betel chewing}

The relationship of OSF to chewing of areca nut/quid or pan masala has been directly related to OSF, whereas chewing or smoking tobacco did not increase the risk for OSF. ${ }^{19}$ In a case-control study from Kerala, India, betel quid alone increased the odds ratio for OSF to 56.2. ${ }^{20}$

\section{Extracellular matrix}

\section{and fibroblast changes}

The most obvious changes occur in the extracellular matrix of the submucous tissue layer. Fibrosis is associated with quantitative and qualitative alterations of collagen deposition within the subepithelial layer of the oral mucosa. This is partly due to marked deficiencies in collagen and fibronectin phagocytosis by fibroblasts caused by betel nut alkaloids (arecoline, arecaidine). ${ }^{21}$ On the other hand, tannins from areca nuts increase collagen fiber resistance to collagenase. ${ }^{22}$

In vitro, areca nut extract suppresses the synthesis of $\left[{ }^{3} \mathrm{H}\right]$ proline and the growth and attachment to collagen of oral fibroblasts in a dose-dependent manner. ${ }^{23}$ Pretreatment of oral mucosa fibroblasts with other areca nut compounds such as buthionine sulfoximine or diethyl maleate potentiates the cytotoxic effects. ${ }^{24}$ Overexpression of stress protein colligin was found in $70 \%$ of OSF patients. It has been suggested that colligin may contribute to the increased deposition of collagen I and thereby to fibrosis development in oral submucosa. ${ }^{25} \mathrm{CD} 34-\mathrm{a}$ marker of mucosal vascular endothelium - and basic fibroblast growth factor are both increased in OSF and demonstrate an association to the stage of fibrosis. ${ }^{26}$

Arecoline - the major compound of areca nut - can induce various growth factors in OSF fibroblasts in vitro, like insulin-like growth factor-1 and keratinocyte growth factor-1, and basic protein cystatin $\mathrm{C},{ }^{27-29}$ but inhibits proinflammatory cytokines like interleukin- $6 .{ }^{30}$ Arecoline stimulates another key molecule in the regulation of fibrosis - the hypoxiainducible factor- $1 \alpha$ - in a dose-dependent manner. ${ }^{31}$

\section{Copper}

Copper is implicated in the pathogenesis of fibrotic disorders because it stimulates collagen synthesis in oral fibroblasts. ${ }^{32}$ Elevated serum copper levels are associated with duration of betel nut chewing and severity of OSF. ${ }^{33}$

Areca nuts contain high copper concentrations compared to other nuts, and copper becomes liberated during chewing. Mass absorption spectrometry of buccal mucosa detected a mean tissue copper level of $5.5 \pm 2.9 \mu \mathrm{g} / \mathrm{g}$ in patients with OSF compared with $4 \pm 1.9 \mu \mathrm{g} / \mathrm{g}$ in controls. Copper has been detected in the epithelium and the connective tissue of the OSF specimens. ${ }^{34}$ Copper levels are significantly higher in commercial areca nut products compared with raw areca nut. ${ }^{35}$

\section{Immune system}

Betel quid affects the immune system. The levels of transforming growth factor (TGF)- $\beta$ and interferon (IFN)- $\gamma$ are 
lower in mononuclear cells from OSF patients than from controls..$^{36,37}$

\section{Antioxidant status and cytokines}

Glutathione S-transferases (GST) are part of the antioxidant system. GSTT1 and GSTM1 null phenotypes increase the risk of OSF. ${ }^{38}$ Reduced glutathione levels in betel quid users are related to raised levels of the proinflammatory interleukin- $6{ }^{39}$ Diminished levels of superoxide dismutase but increased levels of malondialdehyde - a lipid peroxidation product have been detected in OSF. ${ }^{40}$

\section{The role of tobacco addition}

Several surveys show an increase in the incidence of OSF when areca nut and tobacco consumption are combined. A relative risk of 489 has been reported for OSF in consumers of areca nut/tobacco compared with nonusers. ${ }^{41}$ The consumers of mixed products are often younger. ${ }^{10,42}$ OSF develops faster in these patients (after 2.7 years) than in betel quid chewers (after 8.6 years). Cancerous transformation appeared at an early age. ${ }^{43}$

Both genotoxicity and carcinogenicity of areca nut and betel quid with or without tobacco admixture are well documented. Nitrosamines, reactive oxygen species, and depletion of endogenous anti-oxidant capacity are the dominant contributors. ${ }^{38,44}$ Esophageal subepithelial fibrosis is seen more frequently in patients who had consumed areca nut and tobacco for longer than 5 years. ${ }^{45}$

\section{Changes in gene expression and activity}

More recently, the expression profiles of genes in OSF and normal oral mucosa have been studied more intensively. In one study, 14,500 genes were analyzed using gene chip arrays. The study demonstrated 716 genes were upregulated and 149 genes were downregulated in OSF. The gene expression profiles of normal controls and OSF patients were clearly distinct, in particular the genes involved in immune response, inflammatory response, and TGF- $\beta$-induced epithelialmesenchymal transition. ${ }^{46}$

In a comprehensive analysis of water-soluble and ethanolsoluble areca nut constituents, it was demonstrated that both alkaloid and polyphenol fractions induced TGF- $\beta$ signaling in human keratinocytes. Involved genes included $T G F-\beta 2$, $S M A D-3$, matrix metalloproteinase $(M M P) 1, M M P 2$, and $M M P 9$, and others. In contrast, no TGF signaling was induced in fibroblasts. ${ }^{47}$

It can be assumed that direct effects on epithelial cells with TGF- $\beta$ activation can suppress antifibrogenetic cytokines, including bone morphogenetic protein-7 and stimulated fibroblast activity. Both OSF and oral SCC development are quite complex and it is unlikely that a single factor is responsible. ${ }^{48}$

\section{Related conditions in oral submucous fibrosis}

Betel nut chewers are also prone to benign and malignant diseases other than OSF. These diseases can occur intraorally, but also in the descending parts of the gastrointestinal tract, like esophagus or liver. Malnutrition and hepatitis virus infection are independent risk factors. ${ }^{49}$

Betel chewing leads to blood-red saliva that stains teeth and gingiva. The teeth may become red-brown to nearly black (Figure 2). ${ }^{1,13}$ Betel chewer's mucosa (BCM) is characterized by a brownish-red discoloration and an irregular epithelial surface (Figures 3 and 4). The prevalence of BCM reaches up to $60 \%$ with a preference for female sex. The epithelium is often hyperplastic (Figure 4). In contrast to OSF, BCM is not premalignant. ${ }^{50-52}$

Oral leukoplakia and OSF are clinically distinct premalignant states that precede the development of oral SCC. Oral leukoplakia is an early sign of mucosal damage. It can appear as macular, plaque-like, erosive, or verrucous lesion with a homogeneous or speckled white appearance. Erythroplakia would be the reddish counterpart that poses a greater risk for malignant transformation into invasive SCC (Figure 5). ${ }^{1,53}$

In more-advanced OSF, fibrosis is a hallmark leading to impairment in mouth opening, speaking and swallowing (Figures 6 and 7).,

Oral cancer, in particular oral SCC, has been linked to areca nut chewing. The most common symptoms are related

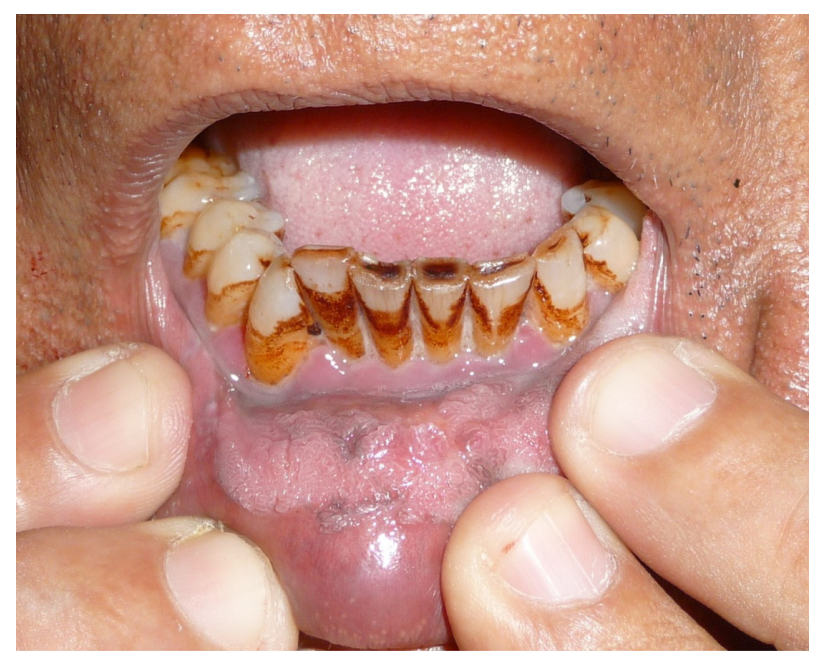

Figure 2 Dental staining and irregular cobble-stone pattern of oral mucosa. 


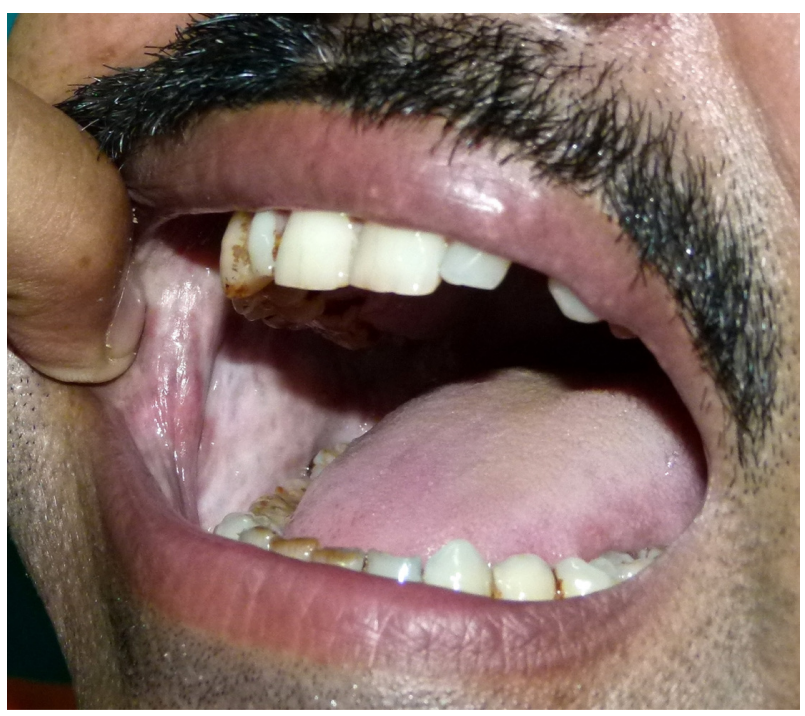

Figure 3 Blanching of buccal mucosa in oral submucous fibrosis.

to later stages of cancer, like odynophagia, oral ulcers, or ulcer pain. ${ }^{54}$ Patients with oral SCC and OSF are younger, show a higher grade of tumor differentiation, and a lower incidence of nodal and extracapsular spread (Figure 8). ${ }^{55}$

Oral cancer accounts for up to $40 \%$ of all malignancies in Asia. ${ }^{56,57}$ Tobacco smoking and chewing betel quid containing tobacco are the major risk factors for oral cancer, whereas betel quid without tobacco significantly increased oral cancer risk in only one study. ${ }^{58}$ OSF makes oral cancer 19.1 times more likely. ${ }^{8,59}$

Attempts have been made to identify specific molecular events as prognostic markers to identify oral precancerous

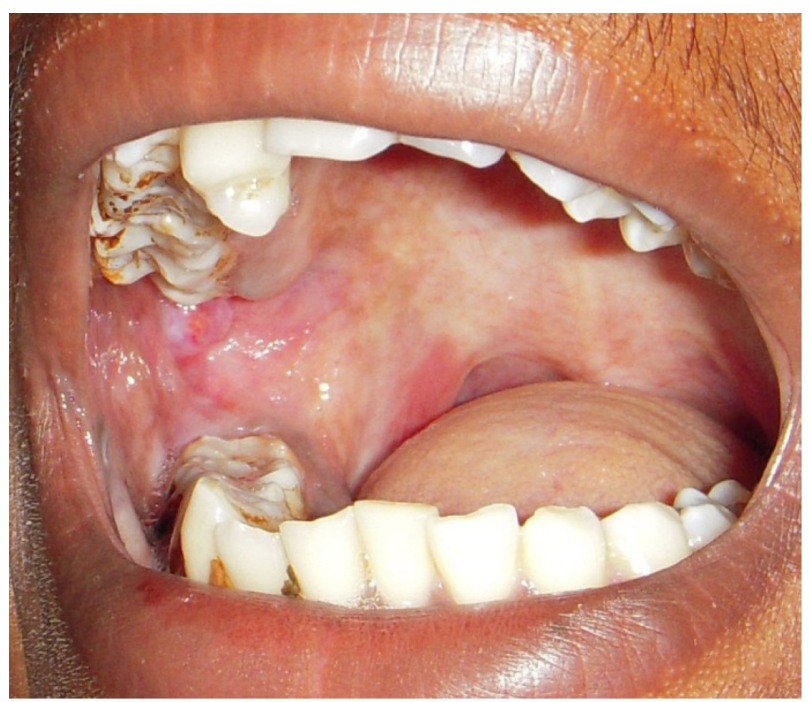

Figure 4 Redness and irregular cobble-stone appearance in oral submucous fibrosis. Note: In such cases a biopsy is recommended to exclude initial oral squamous cell carcinoma.

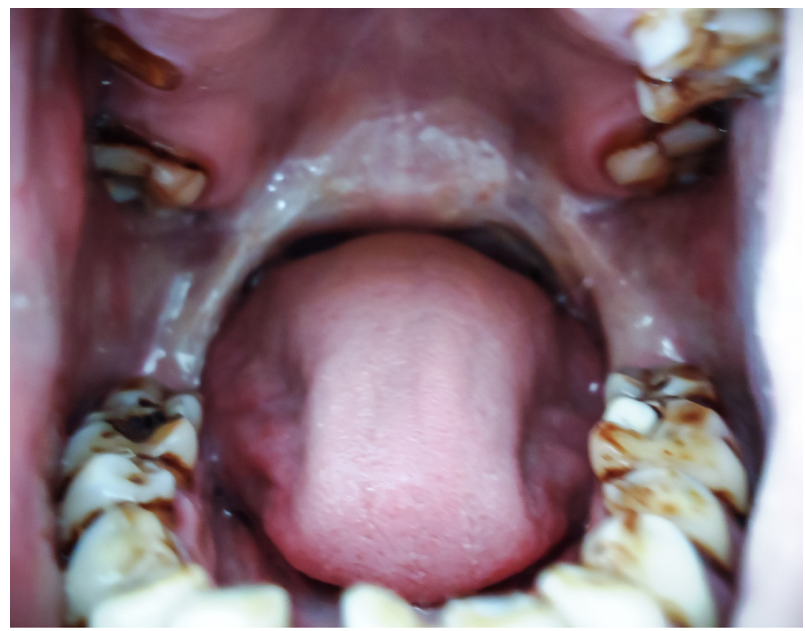

Figure 5 Blanching present on soft palate of patient with oral submucous fibrosis.

lesions with higher malignant potential. The expression of TGF- $\alpha$ and epidermal growth factor-receptor was upregulated in oral leukoplakia, OSF, and oral SCC relative to normal oral mucosa. ${ }^{60}$

Arecoline is considered the most important etiological factor, but addition of peroxynitrite (a reaction product of cigarette smoking) and nicotine acted as a synergistic effect on the arecoline-induced cytotoxicity and glutathione depletion. ${ }^{1,61-64}$ Other factors associated with malignant transformation of OSF have been identified (Table 2). ${ }^{65-77}$

Esophageal involvement is the most common extraoral manifestation in betel nut chewers. Esophageal abnormalities were seen more frequently in patients who had consumed a combination of areca nut and tobacco; the esophagus may also be involved in about two-thirds of patients. ${ }^{45}$

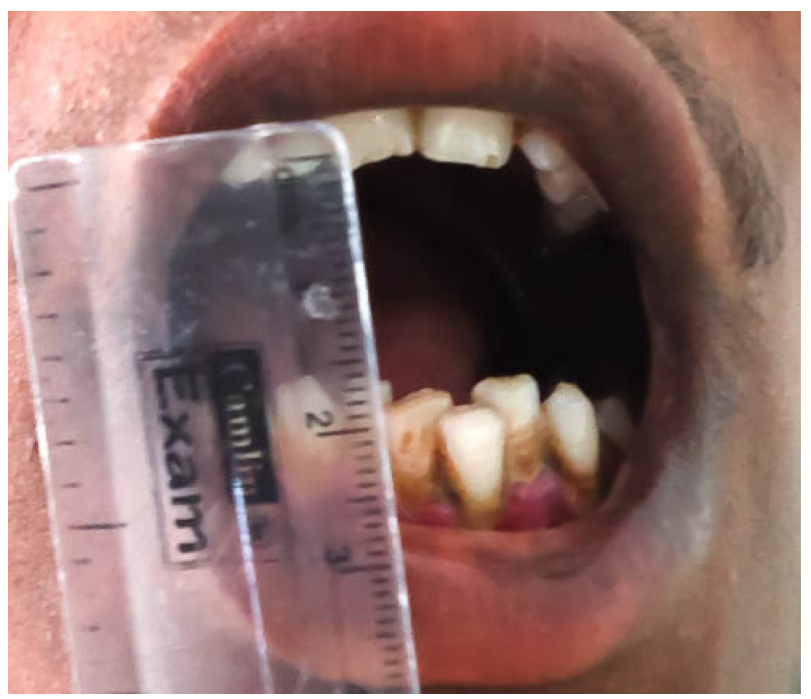

Figure 6 Decreased mouth opening in patient with advanced-stage oral submucous fibrosis. 

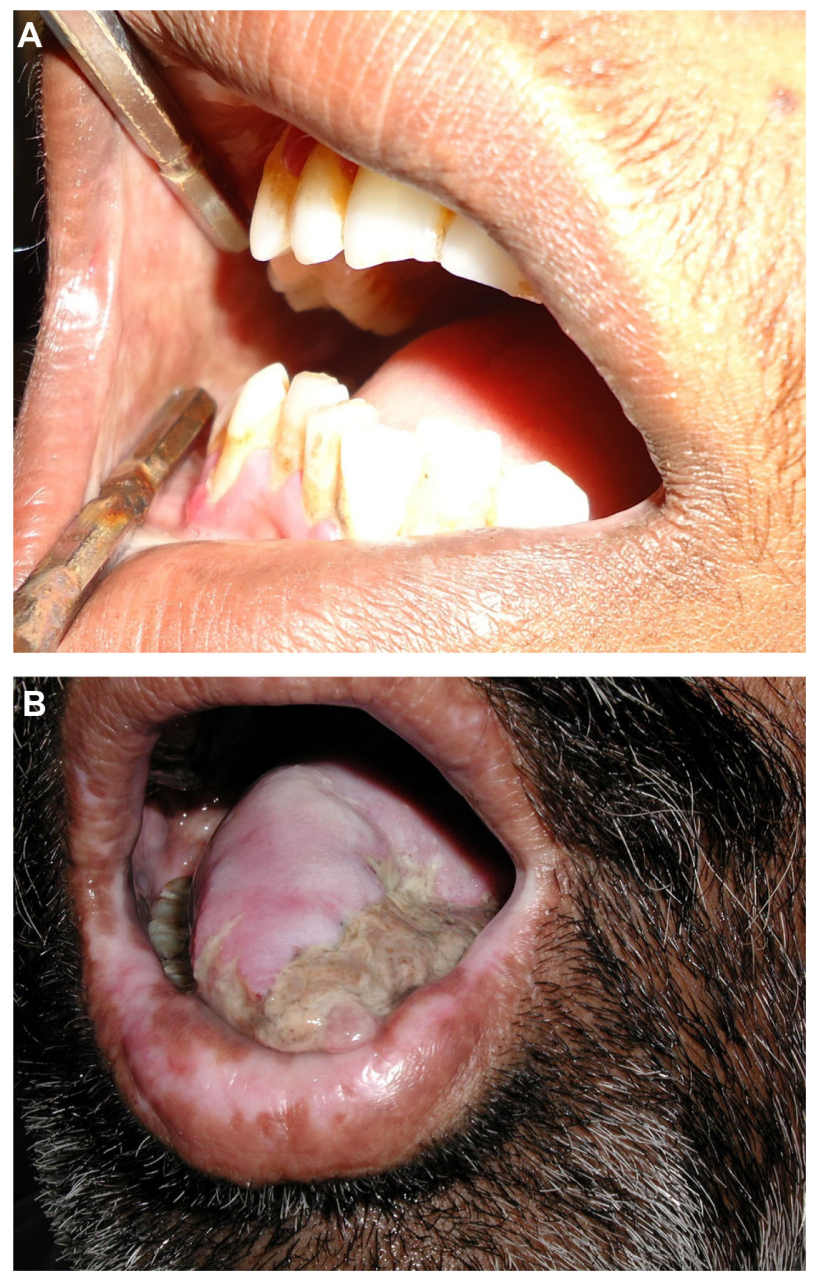

Figure 7 Advanced-stage oral submucous fibrosis.

Notes: (A) Severe decreased mouth opening and blanching seen on buccal mucosa. (B) Leukoplakia of the tongue; a biopsy is indispensable to exclude cancer of the tongue.

Associated visceral organ involvement has not been observed. ${ }^{78}$ Cancer of the esophagus is another possible manifestation, in particular in patients who had been using fermented betel nut with any form of tobacco. ${ }^{79}$

A recent meta-analysis investigated case-control studies and cohort studies from Asia. The authors found an odds ratio for esophageal SCC of 3.05 in areca nut chewers, which was further increased by additional tobacco smoking to $6.79 .{ }^{80,81}$ Betel quid chewing is an independent risk factor of hepatocellular carcinoma. ${ }^{82}$

Recently, evidence has been gained for the association of areca nut chewing and systemic inflammation. In an observational study of 1,112 chewing individuals and 556 controls, the areca nut chewers had an odds ratio of 3.23 for C-reactive protein higher than $10 \mathrm{mg} / \mathrm{dL}$. This might be linked to an increased risk for metabolic diseases, hypertension, and cardiovascular disease..$^{83,84} \mathrm{~A}$ possible link between betel

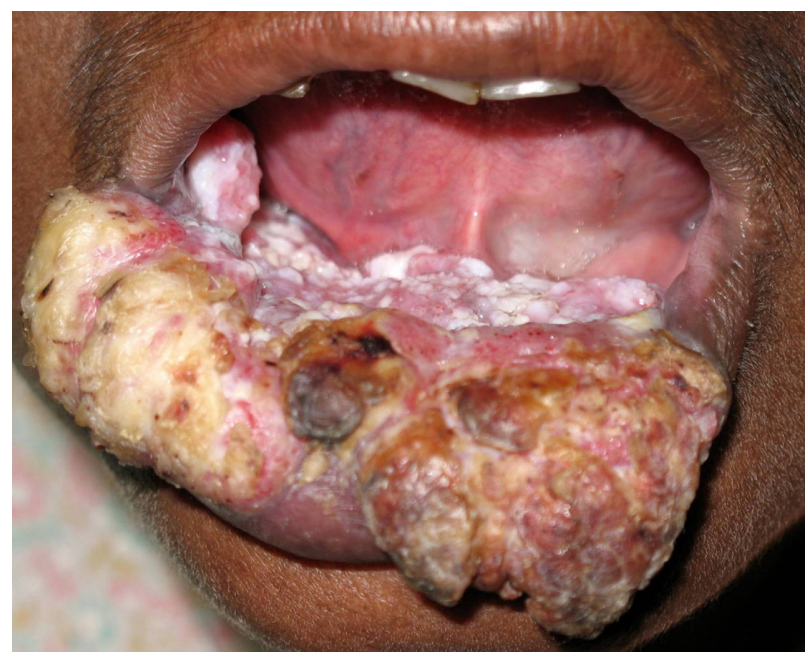

Figure 8 Oral squamous cell carcinoma in a patient with oral submucous fibrosis.

quid chewing and cardiovascular disease could be arecoline. Arecoline is capable of blocking the high-density lipoprotein receptor with a higher affinity than cholesterol. Inhibition of cholesterol endocytosis may contribute to atherosclerosis. ${ }^{85}$

A recent meta-analysis of betel quid and risk of cardiovascular disease concluded that betel quid poses a greater risk than tobacco. ${ }^{86}$ Another meta-analysis concluded that betel quid is associated with two major disorders of metabolic syndrome - diabetes mellitus and central obesity. ${ }^{87}$

\section{Diagnostics}

The hallmark of diagnosing OSF is clinical and histological. Clinically, one or more of the following symptoms should be present:

- Blanching of oral mucosa defined as a persistent, white, marble-like appearance of the oral mucosa, which may be localized, diffuse or reticular

- Tough, leathery texture of the mucosa

- Palpable, whitish, fibrous bands.

This should be accompanied by histopathological investigations. OSF is characterized by epithelial atrophy with loss of rete ridges and hyalinization of the lamina propria and the underlying muscle (Table 1). ${ }^{1}$

The initial pathology of OSF is characterized by mixed inflammation and edema, and large fibroblasts (Figure 9). Later, collagen bundles with early hyalinization are seen, and the inflammatory infiltrate contains lymphocytes and plasma cells, occasionally resembling lichenoid mucositis. ${ }^{88}$

In more-advanced stages, OSF is characterized by formation of thick bands of collagen and hyalinization extending into the submucosal tissues and decreased vascularity (Figure 10A and B). The epithelium becomes thinner 
Table 2 Factors associated with malignant transformation of oral submucous fibrosis

\begin{tabular}{|c|c|c|c|}
\hline Molecules & Description & Findings & References \\
\hline 0(6)-methylguanine-DNA & $\begin{array}{l}\text { Methyltransferase DNA } \\
\text { repair enzyme }\end{array}$ & $\begin{array}{l}\text { Low levels associated with advanced oral SCC and lymph } \\
\text { node involvement }\end{array}$ & 65 \\
\hline Mutations of $\mathrm{p} 53$ & Tumor suppressor gene & $\begin{array}{l}\text { Degree of p53 staining increased with morphologic transformation } \\
\text { of epithelial cells, associated with progression of oral SCC }\end{array}$ & $66-72$ \\
\hline $\begin{array}{l}\text { pl6INK4alpha/pI9ARF } \\
\text { mutations }\end{array}$ & $\begin{array}{l}\text { pl6 regulated GI } \\
\text { proliferation }\end{array}$ & p53 independent pathway of tumorigenesis & 68 \\
\hline MDM2-P2 promoter & Transcriptional target of $p 53$ & Elevated levels of MDM2 protein in dysplastic lesions and oral SCCs & 72 \\
\hline C-jun & Protooncogene & Chronic stimulation by areca nut and arecoline leading to oral SSC & 73 \\
\hline mtDNA mutations & Mitochondrial DNA & Contributor to the early phase of oral carcinogenesis & 74 \\
\hline HSP70 & Heat shock protein & $\begin{array}{l}\text { Significant correlation of HSP70 expression with consumption of betel } \\
\text { and tobacco; in patients with premalignant lesions median transition } \\
\text { time (premalignancy to malignancy) was significantly shorter in } \\
\text { HSP70 overexpressing cases; oral cancer patients with elevated } \\
\text { levels of HSP70 showed decreased median disease-free survival time }\end{array}$ & 75 \\
\hline HSP27 & Heat shock protein & Increased in betel nut-induced oral SCC due to direct action of arecoline & 76 \\
\hline
\end{tabular}

Abbreviation: SCC, squamous cell carcinoma.

or hyperkeratotic. Inflammation and fibrosis of minor salivary glands may develop. Muscle degeneration will occur in advanced stages of OSF. ${ }^{1,82,89}$ In vivo autofluorescence from buccal mucosa seems to be an interesting noninvasive tool to differentiate normal mucosa from OSF and early carcinoma. ${ }^{82}$

\section{Prevention and treatment}

Betel nut chewing is a major risk factor for health, with the propensity for the development of malignancies of the

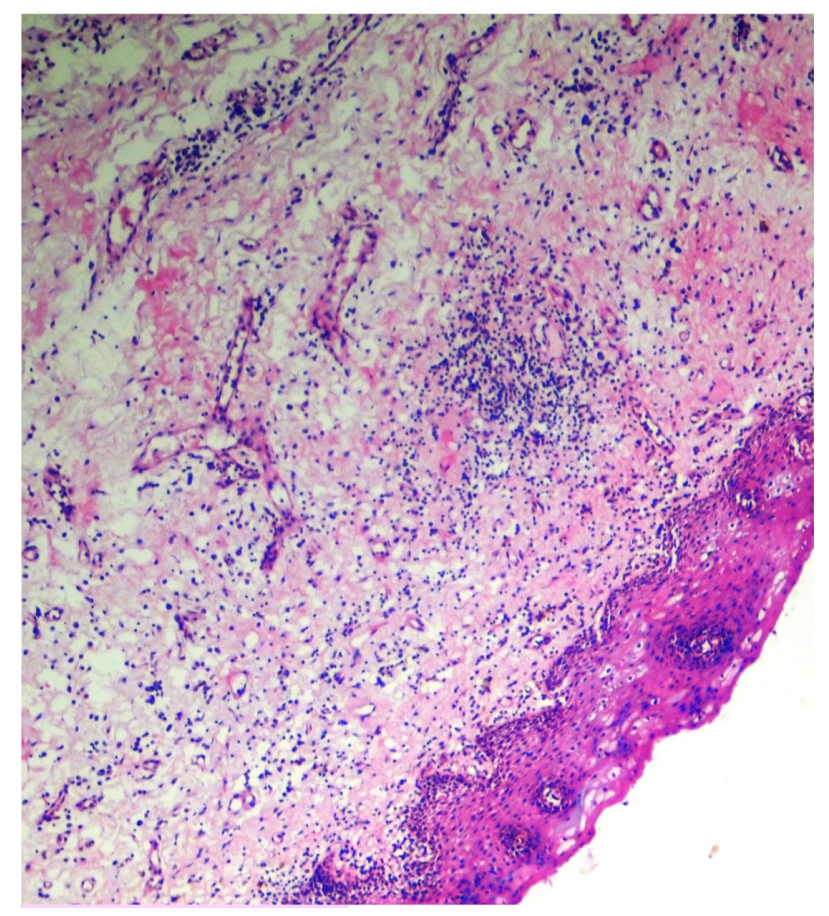

Figure 9 Histopathological picture showing initial stage of oral submucous fibrosis. Note: Hematoxylin and eosin staining, $\times 10$. gastrointestinal tract. The combination of risk factors like betel nut and tobacco chewing, tobacco smoking, and alcohol increases the risk of severe disease like oral SCC. Health education will probably have an influence on this habit. Lessons learned from tobacco smoking, however, argue against rapid changes due to education and information alone.

Asian immigrant communities are growing in Western countries. Some authors have suggested implementation of an oral cancer screening by health care providers. On the other hand, the concept of screening of an asymptomatic patient is not well understood by many immigrants. ${ }^{90}$ Physicians and dentists in the Western world should know about OSF to make an early diagnosis that will help to reduce morbidity and mortality. ${ }^{91,92}$

Conventional therapies in the treatment of OSF are empirical and symptomatic in nature. The major targets of treatment can be summarized as:

- anti-inflammatory

- oxygen radical-scavenging

- antifibrotic. $^{1}$

In many cases, combined drug treatment is performed, although controlled clinical trials are completely lacking. In other patients, depending on severity of disease, physical therapy and/or surgery is added to drug therapy. ${ }^{93}$

Here we will focus on pharmacological therapies, although patients might benefit from physical therapy in conjunction with drug treatment. The more advanced OSF is, the more limited the efficacy of pharmacological treatment. Patients may benefit from surgery or laser surgery in such situations. $^{94-96}$

During the early inflammatory phase of OSF, corticosteroids are of potential benefit, as suggested by in vitro studies. 

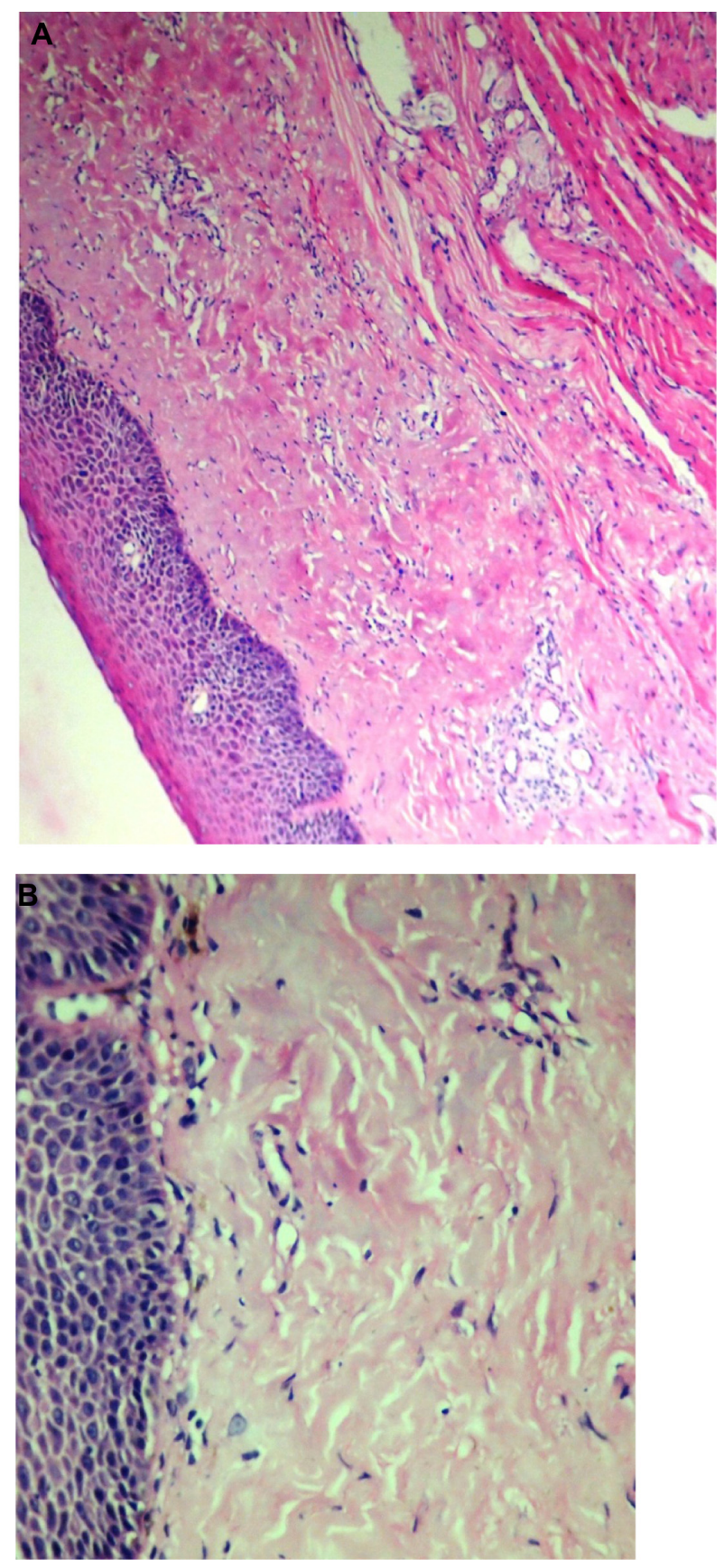

Figure 10 Histopathological picture showing advanced stage of oral submucous fibrosis.

Notes: (A) Hematoxylin and eosin staining, $\times 100$. (B) Closer view (hematoxylin and eosin staining, $\times 400$ ).

OSF has also been treated with hyaluronidase, chymotrypsin and collagenase, pentoxifylline, nylidrin hydrochloride, iron, and lycopene among others, but the level of evidence for any of these attempts is low. ${ }^{94}$

A 6-week course of intralesional injections of $4 \mathrm{mg}$ dexamethasone $/ \mathrm{mL}$ and 1,500 U hyaluronidase twice weekly improved trismus and other clinical parameters associated with fibrosis. In addition, autofluorescence of the affected mucosa normalized for collagen and nicotinamide adenine dinucleotide (reduced form) spectra. ${ }^{96}$

A combination of micronutrients and minerals was evaluated in a single-arm study. Significant improvement in symptoms was observed after 1-3 years of treatment. The interincisor distance was stable in $49 \%$ of patients and improved in $41 \%$, and leukoplakia regressed. ${ }^{97}$

Oxitard is a phytopharmacological complex of antioxidant activity. In a group of 120 OSF patients, efficacy of oxitard two capsules per day was compared to topically applied $0.5 \%$ aloe vera three times daily for 3 months. Subjective symptoms like burning pain and difficulty in swallowing, and mouth opening and tongue protrusion were significantly more improved with oxitard. ${ }^{98}$

Lactoferrin is a biologically active compound of bovine milk. Lactoferrin can also be produced by recombinant technology. The compound is not only immune modulating, resulting in increased antiviral and antibacterial activity of intestinal mucosa, but improves cancer surveillance and has anti-inflammatory effects. ${ }^{99}$

IFN- $\gamma$ that inhibits the collagen synthesis was given intralesionally in an open uncontrolled study. IFN- $\gamma$ treatment showed improvement in the patient's mouth opening with a net gain of $8 \pm 4 \mathrm{~mm}(42 \%)$ of interincisor distance 6 months later. Histochemical investigations demonstrated effects on inflammation and collagen metabolism in favor of antifibrotic activity. ${ }^{100}$

Standardized treatment of OSF does not exist, but some interesting and promising drugs are available (Table 3). ${ }^{93,98,101-}$ ${ }^{107}$ Controlled, prospective multicenter trials seem to be necessary. Careful monitoring of these patients is mandatory so as not to overlook early and treatable stages of oral SCC. Whenever SCCs develop, there is no special treatment but standard surgical, radiotherapeutic, and chemotherapeutic therapy like in other SCCs.

There are a number of potentially beneficial drugs that have yet not been studied systematically in OSF.

1. Modulating agents (antiproteinase, anti-inflammatory) seem to be of interest in gingivitis and periodontitis. ${ }^{102}$

2. Antifibrotic compounds: synthetic drugs that show antifibrotic activities include angiotensin receptor blockers, 3-hydroxy-3-methylglutaryl-coenzyme A (HMG-CoA) inhibitors. ${ }^{108}$ Protein kinase inhibitors have shown potential to decrease lung fibrosis by interaction with key enzymes, eg, focal adhesion kinase and protein kinase B. ${ }^{109}$ Small interfering RNA, statins (simvastatin, lovastatin, pravastatin, fluvastatin, atorvastatin, cerivastatin), peroxisome proliferation-activated 
Table 3 Treatment of oral submucous fibrosis (controlled trials)

\begin{tabular}{|c|c|c|}
\hline Treatment(s) & Outcome & References \\
\hline $\begin{array}{l}\text { Cessation of betel } \\
\text { quid chewing }\end{array}$ & Common sense & $\begin{array}{l}\text { No studies } \\
\text { at all }\end{array}$ \\
\hline $\begin{array}{l}\text { Oxitard twice daily } \\
\text { orally }\end{array}$ & $\begin{array}{l}\text { Better than aloe vera gel } \\
\text { three times/day }\end{array}$ & 98 \\
\hline Aloe vera gel topical & $\begin{array}{l}\text { Better than hyaluronidase }+ \\
\text { dexamethasone submucous } \\
\text { injection }\end{array}$ & 101 \\
\hline $\begin{array}{l}\text { Triamcinolone acetonide }+ \\
\text { salvianolic acid B submucous } \\
\text { injections }\end{array}$ & $\begin{array}{l}\text { Better than triamcinolone } \\
\text { or salvianolic acid alone }\end{array}$ & 102 \\
\hline $\begin{array}{l}\text { Isoxuprine } 10 \text { mg four } \\
\text { times/day + physiotherapy }\end{array}$ & $\begin{array}{l}\text { Better than physiotherapy } \\
\text { alone }\end{array}$ & 103 \\
\hline Pentoxifylline 400 mg/day & Better than placebo & 93 \\
\hline $\begin{array}{l}\text { Hydrocortisone acetate/ } \\
\text { hyaluronidase versus } \\
\text { triamcinolone acetonide/ } \\
\text { hyaluronidase }\end{array}$ & Equal efficacy & 104 \\
\hline $\begin{array}{l}\text { Physiotherapy five } \\
\text { times/week }\end{array}$ & $\begin{array}{l}\text { Better than no treatment } \\
\text { or local injections with } \\
\text { hyaluronidase and steroids }\end{array}$ & 105 \\
\hline Lycopene 16 mg/day & Better than placebo & 106 \\
\hline $\begin{array}{l}\text { Immunized milk + } \\
\text { physiotherapy }\end{array}$ & $\begin{array}{l}\text { Better than physiotherapy } \\
\text { alone }\end{array}$ & 107 \\
\hline
\end{tabular}

receptor gamma antagonists and prostaglandins are capable of blocking the profibrotic activity of connective tissue growth factor CCN2. ${ }^{110}$ In patients with psoriatic arthritis, TNF- $\alpha$ inhibitors exert a hepatoprotective effect and prevent liver fibrosis in vivo. ${ }^{111}$

There is an increasing list of herbal antifibrotic compounds, including quercetin, baicalein, baicalin, wogonin, salvianolic acid B, and emodin, that suppress collagen I expression at both the mRNA and protein levels and also decrease smooth muscle actin expression in vitro. ${ }^{12}$ Some of the flavones like wogonin, baicalein, and baicalin also show anticancer activities and are oxygen radical scavengers. ${ }^{113}$

3. N-acetyl cysteine inhibits collagen gene transcription, and production of collagen in oral mucosal cells in vitro. Furthermore, this compound has a positive impact on intracellular glutathione reserve thereby reducing redox stress to mucosal cells. The compound is not cytotoxic in vitro. ${ }^{114}$

4. Cyclo-oxygenase (COX)-2 inhibitors might be of some benefit during the inflammatory stage of the disease since both immunohistochemistry of OSF lesions and in vitro experiments with buccal mucosal fibroblasts exposed to arecoline demonstrated an upregulation of COX-2. ${ }^{115}$

Available data are summarized in Table 4. There is a need for controlled prospective trials in OSF and for preventive programs as well.
Table 4 Potential compounds for pharmacological treatment of oral submucous fibrosis

\begin{tabular}{lll}
\hline Compound(s) & Effect(s) & Remarks \\
\hline Vitamins & $\begin{array}{l}\text { Oxygen radical } \\
\text { scavengers } \\
\text { Oxygen radical } \\
\text { scavengers } \\
\text { Flavons }\end{array}$ & $\begin{array}{l}\text { In conjunction with } \\
\text { other treatments } \\
\text { In conjunction with } \\
\text { other treatments }\end{array}$ \\
$\begin{array}{l}\text { Pentoxifyllin, } \\
\text { isoxuprine } \\
\text { Corticosteroids }\end{array}$ & $\begin{array}{l}\text { Anti-inflammatory, } \\
\text { In conjunction with }\end{array}$ \\
$\begin{array}{l}\text { TNF- } \alpha \text { inhibitors, } \\
\text { other treatments }\end{array}$ & Antifibrotic \\
$\begin{array}{l}\text { In early stages } \\
\text { ACE inhibitors, } \\
\text { angiotensin receptor } \\
\text { blockers }\end{array}$ & Not yet proven \\
N-acetyl cysteine & Anti-inflammatory, & in OSF \\
anti-oxidant & Not yet proven \\
Protein kinase & Antifibrotic & in OSF \\
inhibitors & Not yet proven \\
Immunized milk & Anti-inflammatory & in OSF \\
Lactoferrin & Anti-inflammatory & Uncontrolled trials \\
& & Not yet proven \\
\hline
\end{tabular}

Abbreviations: ACE, angiotensin-converting enzyme; HMG-CoA, 3-hydroxy-3methylglutaryl-coenzyme A; OSF, oral submucous fibrosis; TNF, tumor necrosis factor.

\section{Author contributions}

Dr Verma, Dr Ali and Dr Patil have investigated the patients shown herein. All four authors fulfilled the following four conditions: 1) substantial contributions to conception and design, acquisition of data, or analysis and interpretation of data; 2) drafting the article or revising it critically for important intellectual content; 3) final approval of the version to be published; and 4) agreement to be accountable for all aspects of the work in ensuring that questions related to the accuracy or integrity of any part of the work are appropriately investigated and resolved.

\section{Disclosure}

The authors report no conflicts of interest in this work.

\section{References}

1. Haider SM, Merchant AT, Fikree FF, Rahbar MH. Clinical and functional staging of oral submucous fibrosis. Br J Oral Maxillofac Surg. 2000;38(1):12-15.

2. Ali FM, Patil A, Patil K, Prasant MC. Oral submucous fibrosis and its dermatological relation. Indian Dermatol Online J. 2014;5(3): 260-265.

3. Pandya S, Chaudhary AK, Singh M, Singh M, Mehrotra R. Correlation of histopathological diagnosis with habits and clinical findings in oral submucous fibrosis. Head Neck Oncol. 2009;1:10.

4. Ceena DE, Bastian TS, Ashok L, Annigeri RG. Comparative study of clinicofunctional staging of oral submucous fibrosis with qualitative analysis of collagen fibers under polarizing microscopy. Indian J Dent Res. 2009;20(3):271-276.

5. Patil S, Maheshwari S. Proposed new grading of oral submucous fibrosis based on cheek flexibility. J Clin Exp Dent. 2014;6(3):e255-e258. 
6. Nelson BS, Heischober B. Betel nut: a common drug used by naturalized citizens from India, Far East Asia, and the South Pacific Islands. Ann Emerg Med. 1999;34(2):238-243.

7. Zain RB. Cultural and dietary risk factors of oral cancer and precancer-a brief overview. Oral Oncol. 2001;37(3):205-210.

8. MerchantA, Husain SS, Hosain M, et al. Paan without tobacco: an independent risk factor for oral cancer. Int J Cancer. 2000;86(1):128-131.

9. Chaudhry K. Is pan masala-containing tobacco carcinogenic? Natl Med J India. 1999;12(1):21-27.

10. Gupta PC, Sinor PN, Bhonsle RB, Pawar VS, Mehta HC. Oral submucous fibrosis in India: a new epidemic? Natl Med J India. 1998;11(3): $113-116$.

11. Roy R. Taxes make cigarette firms huff and puff. The Sunday Times of India, Mubai, 12 (17): February 3, 2002, p 1.

12. Heck JE, Marcotte EL, Argos M, et al. Betel quid chewing in rural Bangladesh: prevalence, predictors and relationship to blood pressure. Int J Epidemiol. 2012;41(2):462-471.

13. Norton SA. Betel: consumption and consequences. JAm Acad Dermatol. 1998;38(1):81-88

14. VanWyk CW. Oral submucous fibrosis. The South African experience. Indian J Dent Res. 1997;8(2):39-45.

15. Mathew AL, Pai KM, Sholapurkar AA, Vengal M. The prevalence of oral mucosal lesions in patients visiting a dental school in Southern India. Indian J Dent Res. 2008;19(2):99-103.

16. Yang YH, Lee HY, Tung S, Shieh TY. Epidemiological survey of oral submucous fibrosis and leukoplakia in aborigines of Taiwan. J Oral Pathol Med. 2001;30(4):213-219.

17. IARC Working Group on the Evaluation of Carcinogenic Risks to Humans. Betel-quid and areca-nut chewing and some areca-nut derived nitrosamines. IARC Monogr Eval Carcinog Risks Hum. 2004;85: $1-334$.

18. Al-Rmalli SW, Jenkins RO, Haris PI. Betel quid chewing elevated human exposure to arsenic, cadmium and lead. J Hazard Mater. 2011; 190(1-3):69-74.

19. Sharma AK, Gupta R, Gupta HP, Singh AK. Haemodynamic effects of pan masala in healthy volunteers. J Assoc Physicians India. 2000; 48(4):400-401.

20. Jacob BJ, Straif K, Thomas G, et al. Betel quid without tobacco as a risk factor for oral precancers. Oral Oncol. 2004;40(7):697-704.

21. Chang YC, Hu CC, Lii CK, Tai KW, Yang SH, Chou MY. Cytotoxicity and arecoline mechanisms in human gingival fibroblasts in vitro. Clin Oral Investig. 2001;5(1):51-56.

22. Tilakaratne WM, Klinikowski MF, Saku T, Peters TJ, Warnakulasuriya S. Oral submucous fibrosis: review on aetiology and pathogenesis. Oral Oncol. 2006;42(6):561-568.

23. Tsai CC, Ma RH, Shieh TY. Deficiency in collagen and fibronectin phagocytosis by human buccal mucosa fibroblasts in vitro as a possible mechanism for oral submucous fibrosis. J Oral Pathol Med. 1999;28(2): 59-63.

24. Jeng JH, Tsai CL, Hahn LJ, Yang PJ, Kuo YS, Kuo MY. Arecoline cytotoxicity on human oral mucosal fibroblasts related to cellular thiol and esterase activities. Food Chem Toxicol. 1999;37(7):751-756.

25. Kaur J, Rao M, Chakravarti N, et al. Co-expression of colligin and collagen in oral submucous fibrosis: plausible role in pathogenesis. Oral Oncol. 2001;37(3):282-287.

26. Pandiar D, Shameena P. Immunohistochemical expression of CD34 and basic fibroblast growth factor (bFGF) in oral submucous fibrosis. J Oral Maxillofac Pathol. 2014;18(2):155-161.

27. Tsai CH, Yang SF, Chen YJ, Chou MY, Chang YC. The upregulation of insulin-like growth factor-1 in oral submucous fibrosis. Oral Oncol. 2005;41(9):940-946.

28. Tsai CH, Yang SF, Chen YJ, Chou MY, Chang YC. Raised keratinocyte growth factor-1 expression in oral submucous fibrosis in vivo and upregulated by arecoline in human buccal mucosal fibroblasts in vitro. J Oral Pathol Med. 2005;34(2):100-105.

29. Chung-Hung T, Shun-Fa Y, Yu-Chao C. The upregulation of cystatin C in oral submucous fibrosis. Oral Oncol. 2007;43(7):680-685.
30. Ullah M, Cox S, Kelly E, Moore MA, Zoellner H. Arecoline increases basic fibroblast growth factor but reduces expression of IL-1, IL-6, G-CSF and GM-CSF in human umbilical vein endothelium. J Oral Pathol Med. Epub December 19, 2014.

31. Tsai CH, Lee SS, Chang YC. Hypoxic regulation of plasminogen activator inhibitor-1 expression in human buccal mucosa fibroblasts stimulated with arecoline. J Oral Pathol Med. Epub November 4, 2014.

32. Trivedy C, Meghji S, Warnakulasuriya KA, Johnson NW, Harris M. Copper stimulates human oral fibroblasts in vitro: a role in the pathogenesis of oral submucous fibrosis. J Oral Pathol Med. 2001;30(8): 465-470.

33. Hosthor SS, Mahesh P, Priya SA, Sharada P, Jyotsna M, Chitra S. Quantitative analysis of serum levels of trace elements in patients with oral submucous fibrosis and oral squamous cell carcinoma: A randomized cross-sectional study. J Oral Maxillofac Pathol. 2014;18(1):46-51.

34. Trivedy CR, Warnakulasuriya KA, Peters TJ, Senkus R, Hazarey VK, Johnson NW. Raised tissue copper levels in oral submucous fibrosis. J Oral Pathol Med. 2000;29(6):241-248.

35. Mathew P, Austin RD, Varghese SS, Manojkumar. Estimation and comparison of copper content in raw areca nuts and commercial areca nut products: implications in increasing prevalence of oral submucous fibrosis (OSMF). J Clin Diagn Res. 2014;8(1):247-249.

36. Hsu HJ, Chang KL, Yang YH, Shieh TY. The effects of arecoline on the release of cytokines using cultured peripheral blood mononuclear cells from patients with oral mucous diseases. Kaohsiung J Med Sci. 2001;17(4):175-182.

37. Haque MF, Meghji S, Khitab U, Harris M. Oral submucous fibrosis patients have altered levels of cytokine production. J Oral Pathol Med. 2000;29(3):123-128.

38. Bathi RJ, Rao R, Mutalik S. GST null genotype and antioxidants: risk indicators for oral pre-cancer and cancer. Indian J Dent Res. 2009;20(3): 298-303.

39. Tsai CH, Yang SF, Chen YJ, Chu SC, Hsieh YS, Chang YC. Regulation of interleukin-6 expression by arecoline in human buccal mucosal fibroblasts is related to intracellular glutathione levels. Oral Dis. 2004;10(6): 360-364.

40. Avinash Tejasvi ML, Bangi BB, Geetha P, et al. Estimation of serum superoxide dismutase and serum malondialdehyde in oral submucous fibrosis: a clinical and biochemical study. J Cancer Res Ther. 2014;10(3):722-725.

41. Hazare VK, Goel RR, Gupta PC. Oral submucous fibrosis, areca nut and pan masala use: a case-control study. Natl Med J India. 1998; 11(6):299.

42. Shah N, Sharma PP. Role of chewing and smoking habits in the etiology of oral submucous fibrosis (OSF): a case-control study. J Oral Pathol Med. 1998;27(10):475-479.

43. Babu S, Bhat RV, Kumar PU, et al. A comparative clinico-pathological study of oral submucous fibrosis in habitual chewers of pan masala and betelquid. J Toxicol Clin Toxicol. 1996;34(3):317-322.

44. Nair U, Bartsch H, Nair J. Alert for an epidemic of oral cancer due to use of the betel quid substitutes gutkha and pan masala: a review of agents and causative mechanisms. Mutagenesis. 2004;19(4):251-262.

45. Misra SP, Misra V, Dwivedi M, Gupta SC. Oesophageal subepithelial fibrosis: an extension of oral submucosal fibrosis. Postgrad Med J. 1998;74(878):733-736.

46. Hu Y, Jian X, Peng J, Jiang X, Li N, Zhou S. Gene expression profiling of oral submucous fibrosis using oligonucleotide microarray. Oncol Rep. 2008;20(2):287-294.

47. Khan I, Kumar N, Pant I, Narra S, Kondaiah P. Activation of TGF- $\beta$ pathway by areca nut constituents: a possible cause of oral submucous fibrosis. PLoS One. 2012;7(12):e51806.

48. Wollina U, Verma S, Parikh D, Parikh A. [Oral and extraoral disease due to betel nut chewing]. Hautarzt. 2002;53(12):795-797. German.

49. Reichart PA, Nguyen XH. Betel quid chewing, oral cancer and other oral mucosal diseases in Vietnam: a review. J Oral Pathol Med. 2008;37(9):511-514. 
50. Jeng JH, Hahn LJ, Lin BR, Hsieh CC, Chan CP, Chang MC. Effects of areca nut, inflorescence piper betle extracts and arecoline on cytotoxicity, total and unscheduled DNA synthesis in cultured gingival keratinocytes. J Oral Pathol Med. 1999;28(2):64-71.

51. Ramaesh T, Mendis BR, Ratnatunga N, Thattil RO. The effect of tobacco smoking and of betel chewing with tobacco on the buccal mucosa: a cytomorphometric analysis. J Oral Pathol Med. 1999;28(9): 385-388.

52. Sharan RN, Mehrotra R, Choudhury Y, Asotra K. Association of betel nut with carcinogenesis: revisit with a clinical perspective. PLoS One. 2012; 7(8):e42759.

53. Muttagi SS, Chaturvedi P, Gaikwad R, Singh B, Pawar P. Head and neck squamous cell carcinoma in chronic areca nut chewing Indian women: Case series and review of literature. Indian J Med Paediatr Oncol. 2012;33(1):32-35.

54. Chaturvedi P, Vaishampayan SS, Nair S, et al. Oral squamous cell carcinoma arising in background of oral submucous fibrosis: a clinicopathologically distinct disease. Head Neck. 2013;35(10): 1404-1409.

55. Chandra S. Incidence of oral leukoplakia and "Pan" chewing in Varanasi (India) dental outdoor patients. J Indian Dent Assoc. 1966;38(9):261-263

56. Pindborg JJ, Kiaer J, Gupta PC, Chawla TN. Studies in oral leukoplakias. Prevalence of leukoplakia among 10,000 persons in Lucknow, India, with special reference to use of tobacco and betel nut. Bull World Health Organ. 1967;37(1):109-116.

57. Thomas S, Wilson A. A quantitative evaluation of the aetiological role of betel quid in oral carcinogenesis. Eur J Cancer B Oral Oncol. 1993;29B(4):265-271.

58. Cox S. Oral cancer in Australia - risk factors and distribution. Ann $R$ Australas Coll Dent Surg. 2000;15:261-263.

59. Srinivasan M, Jewell SD. Evaluation of TGF-alpha and EGFR expression in oral leukoplakia and oral submucous fibrosis by quantitative immunohistochemistry. Oncology. 2001;61(4):284-292.

60. Chang MC, Lin LD, Wu HL, et al. Areca nut-induced buccal mucosa fibroblast contraction and its signaling: a potential role in oral submucous fibrosis - a precancer condition. Carcinogenesis. 2013;34(5):1096-1104.

61. Chang YC, Tai KW, Chou MY, Tseng TH. Synergistic effects of peroxynitrite on arecoline-induced cytotoxicity in human buccal mucosal fibroblasts. Toxicol Lett. 2000;118(1-2):61-68.

62. Chang YC, Hu CC, Lii CK, Tai KW, Yang SH, Chou MY. Cytotoxicity and arecoline mechanisms in human gingival fibroblasts in vitro. Clin Oral Investig. 2001;5(1):51-56.

63. Chang MC, Ho YS, Lee PH, et al. Areca nut extract and arecoline induced the cell cycle arrest but not apoptosis of cultured oral $\mathrm{KB}$ epithelial cells: association of glutathione, reactive oxygen species and mitochondrial membrane potential. Carcinogenesis. 2001;22(9): $1527-1535$.

64. Lee SS, Tsai CH, Yu CC, Ho YC, Hsu HI, Chang YC. The expression of $\mathrm{O}(6)$-methylguanine-DNA methyltransferase in human oral keratinocytes stimulated with arecoline. J Oral Pathol Med. 2013;42(8):600-605.

65. Chang YC, Hu CC, Tseng TH, Tai KW, Lii CK, Chou MY. Synergistic effects of nicotine on arecoline-induced cytotoxicity in human buccal mucosal fibroblasts. J Oral Pathol Med. 2001;30(8):458-464.

66. Baral R, Patnaik S, Das BR. Co-overexpression of p53 and c-myc proteins linked with advanced stages of betel- and tobacco-related oral squamous cell carcinomas from eastern India. Eur J Oral Sci. 1998;106(5):907-913.

67. Kannan K, Munirajan AK, Krishnamurthy J, et al. Low incidence of p53 mutations in betel quid and tobacco chewing-associated oral squamous carcinoma from India. Int J Oncol. 1999;15(6):1133-1136.

68. Hsieh LL, Wang PF, Chen IH, et al. Characteristics of mutations in the p53 gene in oral squamous cell carcinoma associated with betel quid chewing and cigarette smoking in Taiwanese. Carcinogenesis. 2001;22(9):1497-1503.
69. Agarwal S, Mathur M, Shukla NK, Ralhan R. Expression of cyclin dependent kinase inhibitor $\mathrm{p} 21 \mathrm{waf} 1 / \mathrm{cip} 1$ in premalignant and malignant oral lesions: relationship with p53 status. Oral Oncol. 1998;34(5):353-360.

70. Ralhan R, Sandhya A, Meera M, Bohdan W, Nootan SK. Induction of MDM2-P2 transcripts correlates with stabilized wild-type 53 in betel-and tobacco-related human oral cancer. Am J Pathol. 2000;157(2):587-596.

71. Ho TJ, Chiang CP, Hong CY, Kok SH, Kuo YS, Yen-Ping Kuo M. Induction of the c-jun protooncogene expression by areca nut extract and arecoline on oral mucosal fibroblasts. Oral Oncol. 2000;36(5):432-436.

72. Lee HC, Yin PH, Yu TN, et al. Accumulation of mitochondrial DNA deletions in human oral tissues - effects of betel quid chewing and oral cancer. Mutat Res. 2001;493(1-2):67-74.

73. Kaur J, Srivastava A, Ralhan R. Expression of 70-kDa heat shock protein in oral lesions: marker of biological stress or pathogenicity. Oral Oncol. 1998;34(6):496-501.

74. Rajendra R, George B, Sivakaran S, Narendranathan N. Visceral organ involvement is infrequent in oral submucous fibrosis (OSF). Indian $J$ Dent Res. 2001;12(1):7-20.

75. Lee SS, Tsai CH, Ho YC, Yu CC, Chang YC. Heat shock protein 27 expression in areca quid chewing-associated oral squamous cell carcinomas. Oral Dis. 2012;18(7):713-719.

76. Tung CL, Lin ST, Chou HC, et al. Proteomics-based identification of plasma biomarkers in oral squamous cell carcinoma. J Pharm Biomed Anal. 2013;75:7-17.

77. Phukan RK, Ali MS, Chetia CK, Mahanta J. Betel nut and tobacco chewing; potential risk factors of cancer of oesophagus in Assam, India. Br J Cancer. 2001;85(5):661-667.

78. Tsai JF, Chuang LY, Jeng JE, et al. Betel quid chewing as a risk factor for hepatocellular carcinoma: a case-control study. $\mathrm{Br} \mathrm{J}$ Cancer. 2001;84(5):709-713.

79. Akhtar S. Areca nut chewing and esophageal squamous-cell carcinoma risk in Asians: A meta-analysis of case-control studies. Cancer Causes Control. 2013;24(2):257-265.

80. Chen PT, Kuan FC, Huang CE, et al. Incidence and patterns of second primary malignancies following oral cavity cancers in a prevalent area of betel-nut chewing: a population-based cohort of 26,166 patients in Taiwan. Jpn J Clin Oncol. 2011;41(12):1336-1343.

81. Haris PS, Balan A, Jayasree RS, Gupta AK. Autofluorescence spectroscopy for the in vivo evaluation of oral submucous fibrosis. Photomed Laser Surg. 2009;27(5):757-761.

82. Shafique K, Mirza SS, Vart P, et al. Areca nut chewing and systemic inflammation: evidence of a common pathway for systemic diseases. J Inflamm (Lond). 2012;9(1):22.

83. Tsai WC, Wu MT, Wang GJ, et al. Chewing areca nut increases the risk of coronary artery disease in Taiwanese men: a case-control study. BMC Public Health. 2012;12:162.

84. Choudhury MD, Chetia P, Choudhury KD, Talukdar AD, DattaChoudhari M. Atherogenic effect of Arecoline: A computational study. Bioinformation. 2012;8(5):229-232.

85. Zhang LN, Yang YM, Xu ZR, Gui QF, Hu QQ. Chewing substances with or without tobacco and risk of cardiovascular disease in Asia: a meta-analysis. J Zhejiang Univ Sci B. 2010;11(9):681-689.

86. Javed F, Al-Hezaimi K, Warnakulasuriya S. Areca-nut chewing habit is a significant risk factor for metabolic syndrome: a systematic review. J Nutr Health Aging. 2012;16(5):445-448.

87. Reichart PA, Warnakulasuriya S. Oral lichenoid contact lesions induced by areca nut and betel quid chewing: a mini review. J Investig Clin Dent. 2012;3(3):163-166.

88. Lee CK, Tsai MT, Lee HC, et al. Diagnosis of oral submucous fibrosis with optical coherence tomography. J Biomed Opt. 2009;14(5): 054008 .

89. Auluck A, Hislop G, Poh C, Zhang L, Rosin MP. Areca nut and betel quid chewing among South Asian immigrants to Western countries and its implications for oral cancer screening. Rural Remote Health. 2009;9(2):1118. 
90. Sukumar S, Coleman HG, Cox SC. Areca nut chewing in an expatriate population in Sydney: report of two cases. Aust Dent J. 2012;57(3): 373-378.

91. Auluck A, Rosin MP, Zhang L, Sumanth KN. Oral submucous fibrosis, a clinically benign but potentially malignant disease: report of 3 cases and review of the literature. J Can Dent Assoc. 2008;74(8): 735-740.

92. Sharma JK, Gupta AK, Mukhija RD, Nigam P. Clinical experience with the use of peripheral vasodilator in oral disorders. Int J Oral Maxillofac Surg. 1987;16(6):695-699.

93. Mehrotra R, Singh HP, Gupta SC, Singh M, Jain S. Pentoxifylline therapy in the management of oral submucous fibrosis. Asian Pac J Cancer Prev. 2011;12(4):971-974.

94. Chole RH, Gondivkar SM, Gadbail AR, et al. Review of drug treatment of oral submucous fibrosis. Oral Oncol. 2012;48(5):393-398.

95. Aziz SR. Lack of reliable evidence for oral submucous fibrosis treatments. Evid Based Dent. 2009;10(1):8-9.

96. Gupta D, Sharma SC. Oral submucous fibrosis - a new treatment regimen. J Oral Maxillofac Surg. 1988;46(10):830-833.

97. Vedeswari CP, Jayachandran S, Ganesan S. In vivo autofluorescence characteristics of pre- and post-treated oral submucous fibrosis: a pilot study. Indian J Dent Res. 2009;20(3):261-267.

98. Patil S, Halgatti V, Maheshwari S, Santosh BS. Comparative study of the efficacy of herbal antioxdants oxitard and aloe vera in the treatment of oral submucous fibrosis. J Clin Exp Dent. 2014;6(3): wwe265-e270.

99. Lönnerdal B. Nutritional roles of lactoferrin. Curr Opin Clin Nutr Metab Care. 2009;12(3):293-297.

100. Haque MF, Meghji S, Nazir R, Harris M. Interferon gamma (IFN-gamma) may reverse oral submucous fibrosis. J Oral Pathol Med. 2001;30(1):12-21.

101. Alam S, Ali I, Giri KY, et al. Efficacy of aloe vera gel as an adjuvant treatment of oral submucous fibrosis. Oral Surg Oral Med Oral Pathol Oral Radiol. 2013;116(6):717-724.

102. Jiang XW, Zhang Y, Yang SK, Zhang H, Lu K, Sun GL. Efficacy of salvianolic acid B combined with triamcinolone acetonide in the treatment of oral submucous fibrosis. Oral Surg Oral Med Oral Pathol Oral Radiol. 2013;115(3):339-344.

103. Bhadage CJ, Umarji HR, Shah K, Välimaa H. Vasodilator isoxsuprine alleviates symptoms of oral submucous fibrosis. Clin Oral Investig. 2013;17(5):1375-1382.
104. Singh M, Niranjan HS, Mehrotra R, Sharma D, Gupta SC. Efficacy of hydrocortisone acetate/hyaluronidase vs triamcinolone acetonide/ hyaluronidase in the treatment of oral submucous fibrosis. Indian $J$ Med Res. 2010;131:665-669.

105. Cox S, Zoellner H. Physiotherapeutic treatment improves oral opening in oral submucous fibrosis. J Oral Pathol Med. 2009;38(2): 220-226.

106. Kumar A, Bagewadi A, Keluskar V, Singh M. Efficacy of lycopene in the management of oral submucous fibrosis. Oral Surg Oral Med Oral Pathol Oral Radiol Endod. 2007;103(2):207-213.

107. Tai YS, Liu BY, Wang JT, Sun A, Kwan HW, Chiang CP. Oral administration of milk from cows immunized with human intestinal bacteria leads to significant improvements of symptoms and signs in patients with oral submucous fibrosis. J Oral Pathol Med. 2001;30(10): 618-625.

108. Reddy MS, Geurs NC, Gunsolley JC. Periodontal host modulation with antiproteinase, anti-inflammatory, and bone-sparing agents. A systematic review. Ann Periodontol. 2003;8(1):12-37.

109. Szabò H, Fiorino G, Spinelli A, et al. Review article: anti-fibrotic agents for the treatment of Crohn's disease - lessons learnt from other diseases. Aliment Pharmacol Ther. 2010;31(2):189-201.

110. Garneau-Tsodikova S, Thannickal VJ. Protein kinase inhibitors in the treatment of pulmonary fibrosis. Curr Med Chem. 2008;15(25): 2632-2640.

111. Brigstock DR. Strategies for blocking the fibrogenic actions of connective tissue growth factors (CCN2): From pharmacological inhibition in vitro to targeted siRNA therapy in vivo. J Cell Commun Signal. 2009;3(1):5-18.

112. Seitz M, Reichenbach S, Möller B, Zwahlen M, Villiger PM, Dufour JF. Hepatoprotective effect of tumour necrosis factor alpha blockade in psoriatic arthritis: a cross-sectional study. Ann Rheum Dis. 2010;69(6): 1148-1150.

113. $\mathrm{Hu} \mathrm{Q}$, Noor $\mathrm{M}$, Wong $\mathrm{YF}$, et al. In vitro anti-fibrotic activities of herbal compounds and herbs. Nephrol Dial Transplant. 2009;24(10): 3033-3041.

114. Li-Weber M. New therapeutic aspects of flavones: the anticancer properties of Scutellaria and its main active constituents Wogonin, Baicalein and Baicalin. Cancer Treat Rev. 2009;35(1):57-68.

115. Sato N, Ueno T, Kubo K, et al. N-Acetyl cysteine (NAC) inhibits proliferation, collagen gene transcription, and redox stress in rat palatal mucosal cells. Dent Mater. 2009;25(12):1532-1540.
Clinical, Cosmetic and Investigational Dermatology

\section{Publish your work in this journal}

Clinical, Cosmetic and Investigational Dermatology is an international, peer-reviewed, open access, online journal that focuses on the latest clinical and experimental research in all aspects of skin disease and cosmetic interventions. All areas of dermatology will be covered; contributions will be welcomed from all clinicians and

\section{Dovepress}

basic science researchers globally. This journal is indexed on CAS The manuscript management system is completely online and includes a very quick and fair peer-review system, which is all easy to use. Visit http://www.dovepress.com/testimonials.php to read real quotes from published authors. 